\title{
Organic Quarantine Treatments for Tree Fruits
}

\author{
Lisa G. Neven ${ }^{1}$ \\ USDA-ARS, Yakima Agricultural Research Laboratory, 5230 Konnowac Pass Road, Wapato, WA, 98951
}

Additional index words. Malus, Prunis, apple, cherry, peach, nectarine, codling moth, oriental fruit moth, Western cherry fruit fly

\begin{abstract}
Organic production of pome and stone fruits in the United States has greatly increased during the past few years. To compete and enter lucrative export markets, these fruit must meet stringent quarantine requirements. For some countries, these requirements dictate that the fruit crops must be treated with a synthetic chemical fumigant, which is not compliant with organic standards. Therefore, nonchemical quarantine treatments for organically produced pome and stone fruits have been developed using the Controlled Atmosphere/Temperature Treatment System (or CATTS) technology. This technology applies a short-term heat treatment under a low- $\mathrm{O}_{2} /$ high- $\mathrm{CO}_{2}$ environment, and is effective in controlling the most prominent quarantine insect pests while maintaining commodity quality. The technology has progressed beyond laboratory-scale research units to 1- to 2-ton commercial units. The development of these treatments and their effect on both insect mortality and commodity quality are discussed.
\end{abstract}

The presence or potential presence of internal feeding insects in tree fruits grown in the United States has caused the development and implementation of specific quarantine procedures to prevent the accidental introduction of these pests to areas where they do not occur. Some countries require the issuance of a phytosanitary certificate under a systems approach (Northwest Horticultural Council, 2006). Although organic apples can meet the stringent provisions of the "systems" approach (incorporation of production, harvesting, and packing practices) to meet quarantine requirements, the requirement for methyl bromide fumigation for entry into other countries does not coincide with current United States and international

This research was funded by grants from the Washington State Tree Fruit Research Commission, California Tree Fruit Agreement, U.S. Pear Board, Oregon Cherry Growers Association, U.S. Department of Agriculture-Foreign Agricultural Service, and U.S. Department of AgricultureAnimal and Plant Health Inspection Service.

Mention of a trademark, proprietary product, or vendor does not constitute a guarantee or warranty of the product by the U.S. Department of Agriculture and does not imply its approval to the exclusion of other products or vendors that also may be suitable. I would like to thank all my co-authors who have worked with me on developing the Controlled Atmosphere/Temperature Treatment System (CATTS) technology, especially Drs. E.J. Mitcham, K. Shellie, D. Obenland, S. Drake, and G. Hallman. I would also like to thank all those from the staff at the Yakima Agricultural Research Laboratory (YARL) who provided technical assistance, including L. Rehfield-Ray, A. KennyChapman, R. Barnhart, D. Hallauer, T. Wurtz, M. Morford, J. Schlaman, J. Jewett, M. Heidt, and M. Watkins. I would also like to thank my co-workers at YARL for their support of my research and cooperation in lending technical assistance. I would like to thank my cooperators who donated time and resources to the development of CATTS treatments, especially H. Ostenson (PacOrganic), K. Mathison (Stemilt), R. Valicoff (Valicoff Fruit), Snokist Fruit, Inland-Joseph Fruit, and Valley Fruit. I would also like to thank Dan Black and all the employees of Techni-Systems (Chelan, WA) for developing the CATTS chambers and the control system, and for their continued technical support.

${ }^{1}$ To whom reprint request should be addressed; email neven@yarl.ars.usda.gov. organic standards (McEvoy, 2003; National Organic Program, 2006).

Most nonchemical quarantine treatments involve the application of high or low temperatures (Neven, 2000, 2003; Wang et al., 2006). Combinations of low-temperature and controlled atmospheres (CAs) (low $\mathrm{O}_{2} /$ elevated $\mathrm{CO}_{2}$ ) have also been widely used (Hallman, 1994). High-temperature treatments have been traditionally developed for tropical and subtropical fruits and vegetables (Armstrong, 1994). Low-temperature CA treatments were seen as the only viable method of disinfestation for temperate crops, such as apples and pears. However, research from Israel in the 1990s indicated that apples could tolerate high-temperature treatments and that these treatments could also effectively alleviate some postharvest disorders such as superficial storage scald (Klein, 1994; Klein and Lurie, 1992; Klein et al., 1990; Lurie et al., 1990, 1991). Although the temperatures and heating rates used in these studies did not effectively control internal feeding pests such as codling moth (CM) (Neven and Rehfield, 1995), they suggested that heat treatments for apples to control these pests could be developed (Neven, 1998a,b; Neven and Rehfield-Ray, 2006b; Neven et al., 1996).

Deciduous tree fruits were not thought to be able to tolerate high-temperature quarantine treatments. In addition, they way the fruit are harvested, with a wide range of fruit sizes represented in any given load, posed a potential thermodynamic and logistical problem. However, the treatment of a wide range of fruit sizes using slow heating allows for equilibrial heating of the fruit, which was based on fruit thermal capacity. Other heat treatments performed on tropical and subtropical fruits do not use this approach. Those treatments ramp up the chamber temperature as quickly as possible and hold at the chamber target temperature as the fruit heats up, often with great differentials between chamber and fruit surface temperatures and fruit surface and core temperatures. We found in our work with apples (Neven et al., 1996) that large differences in chamber-to-fruit surface temperatures caused significant phytotoxicity. However, if we took the rate at which the fruit naturally heated and used that linear rate to treat the fruit, phytotoxicity was no longer a problem (Neven et al., 2001; Obenland et al., 2005).

It is known that plants have a relatively high capacity for anaerobic metabolism, whereas insects have a very limited capacity for anaerobic metabolism. The presence of oxygen is critical for insect acclimation to thermal stress (Yocum and Denlinger, 1994; Neven, 2003). In addition, terrestrial insect respiration is chiefly regulated by the presence of carbon dioxide. These differences in plant and insect physiological responses to thermal and respiratory stress were capitalized on by the invention of the Controlled Atmosphere Temperature Treatment System (CATTS) technology (Neven and Mitcham, 1996). This system combined the application of a moist-forced hot air (MFA) or vaporforced hot air (VFA) under a CA. Moistforced hot air refers to hot forced air treatments conducted under a noncondensing humidity environment, whereas VFA refers to hot forced air treatments under a condensing humidity environment. This technology is similar to existing VFA and MFA treatment systems currently approved and are in use for a number of commodities destined for numerous countries throughout the world. The only difference in CATTS is the application of a CA. However, this addition is critical for the success of this treatment in providing appropriate pest control and preserving commodity quality. Research using CATTS or CATTS-type technology has been increasing for the past 11 years (Neven 2004, 2005; Neven and Drake, 2000a,b; Neven and Mitcham, 1996; Neven and Rehfield-Ray, 2006b; Neven et al., 2001, 2006; Obenland et al., 2005; Shellie et al., 2001; Whiting and Hoy,1997; Whiting et al., 1999; Yahia, 2000a,b,c).

This review describes a body of work on the development of a CATTS treatment for disinfestation of deciduous tree fruits from internal feeding pests. How these treatments were developed in regard to fruit tolerance and insect intolerance is described. Largescale efficacy and confirmatory tests were performed on the major quarantine insects in both laboratory- and commercial-scale CATTS treatment chambers. The effects of these treatments on both fruit quality and 
insect mortality are discussed in the following sections.

\section{SWEET CHERRIES}

Perhaps the most challenging project was to develop a high-temperature treatment for sweet cherries. Every cherry grower in the world knows that cherries have to be kept cold after harvest to maintain quality. However, sweet cherries on the tree experience rather dramatic changes in temperature $(\mathrm{G}$. Brown, pers. comm.). The ability of cherries to tolerate high preharvest temperatures indicated that postharvest tolerance to CATTS would be likely.

The two major pests of quarantine concern in sweet cherries grown in the Pacific Northwest are codling moth (CM) (Cydia pomonella) and Western cherry fruit fly (WCFF) (Rhagoletis indifferens). Codling moth is a lesser concern on sweet cherries, because sweet cherries are known to be a poor host for CM (Hansen and Rehmke, 2003). Western cherry fruit fly is a risk, but there is a zero tolerance for this pest in the orchard and at the packing shed. However, because both insects pose a risk to foreign markets like Australia and Japan (in the case of WCFF and CM respectively) and domestic markets like California (for WCFF), suitable treatments must be developed to protect against the accidental introduction of these pests.

Most tolerant stage of codling moth. The first step in developing a treatment is the determination of the developmental stage of the target pest that is most tolerant to that particular treatment. That stage will be the subject of larger scale tests to determine efficacy of the treatment. We compared the CATTS tolerance of the three embryonic stages of eggs and the five instars of CM using probit analysis (Neven, 2005). We determined that all egg stages were less tolerant to CATTS treatments than all larval stages. The third and fourth instars were the most tolerant to CATTS $(\mathrm{df}=1, P<0.0001)$, but were about equal to each other in tolerance. Analysis of covariance revealed that the egg stages are about equal to each other in tolerance.

Efficacy tests on codling moth. Third instars were used in the efficacy tests because current methyl bromide fumigation treatments against $\mathrm{CM}$ in sweet cherries destined to Japan are designed to control the third instar (Moffitt et al., 1992; Wearing et al., 2001), and this stage is relatively as tolerant to CATTS as the fourth instar. Also, it is generally recognized by both the United States and Ministries of Agriculture, Forestries, Fisheries (Japan) that the third instar is the stage most likely to be in the fruit at time of harvest (Moffitt et al., 1992). Treatments at $45^{\circ} \mathrm{C}$ for $45 \mathrm{~min}$ at a $1 \mathrm{kPa} \mathrm{O}_{2}, 15 \mathrm{kPa} \mathrm{CO}$ atmosphere with humidity maintained at $2{ }^{\circ} \mathrm{C}$ below dew point and $2 \mathrm{~m} / \mathrm{s}$ air speed were used to treat 5067 third instars, resulting in zero survivors (Table 1) (Neven, 2005). Treatments at $47{ }^{\circ} \mathrm{C}$ for $25 \mathrm{~min}$ at a $1 \mathrm{kPa}$

Table 1. Summary of Controlled Atmosphere/Temperature Treatment System treatments for sweet cherries for control of codling moth (CM) and Western cherry fruit fly (WCFF).

\begin{tabular}{lccccc}
\hline $\begin{array}{l}\text { Chamber } \\
\text { temperature }\end{array}$ & $\begin{array}{c}\text { Time to core } \\
\left({ }^{\circ} \mathrm{C}\right)\end{array}$ & $\begin{array}{c}\text { Total treatment } \\
\text { time }^{\mathrm{y}}(\mathrm{min})\end{array}$ & $\begin{array}{c}\text { Final core } \\
\text { temperature } \\
\left({ }^{\circ} \mathrm{C}^{\mathrm{z}}(\mathrm{min})\right.\end{array}$ & $\begin{array}{c}\text { CM killed } \\
(\mathrm{n})\end{array}$ & $\begin{array}{c}\text { WCFF killed }^{\mathrm{v}} \\
(\mathrm{n})\end{array}$ \\
\hline 45 & $7-9$ & 45 & 44.5 & 5067 & 6315 \\
47 & $7-9$ & 25 & 45.5 & 5759 & 5800 \\
\hline
\end{tabular}

${ }^{\mathrm{z}}$ Critical time for core average temperature to reach $42{ }^{\circ} \mathrm{C}$.

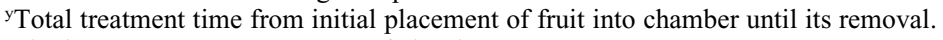

${ }^{x}$ Final core average temperature of cherries.

wNumber of third instar codling moths (CM) killed with zero survivors in efficacy tests.

vEstimated number of Western cherry fruit fly (WCFF) killed with zero survivors in efficacy tests.

All Controlled Atmosphere/Temperature Treatment System treatments conducted at $1 \mathrm{kPaO}_{2}, 15 \mathrm{kPa} \mathrm{CO}_{2}$, with a dew point set at $2{ }^{\circ} \mathrm{C}$ below the lowest fruit surface temperature.

$\mathrm{O}_{2}, 15 \mathrm{kPa} \mathrm{CO}_{2}$ atmosphere with humidity maintained at $2{ }^{\circ} \mathrm{C}$ below dew point and $2 \mathrm{~m} / \mathrm{s}$ air speed were used to treat 5759 third instars, with zero survivors (Table 1) (Neven, 2005). Average control mortality was less than $10 \%$ in all treatments. The number killed was adjusted from the control mortality and larval recovery (insects outside of fruit) during transfer from infesting bins to treatment lugs. These tests indicate that these treatments are efficacious for control of CM larvae in sweet cherries.

Most tolerant stage of Western cherry fruit fly. Western cherry fruit fly is a very difficult insect with which to work because it has a univoltine life cycle (one generation per year) and an obligatory pupal diapause, which is extremely difficult to break. After 4 years of research, determinations regarding the most tolerant WCFF stage were inconclusive (Neven and Rehfield-Ray, 2006a). When mortality of each stage in the two treatments was plotted out, all stages followed a similar curve, and no stage emerged as being most tolerant when we compared mortalities with SEMs.

Efficacy tests of Western cherry fruit fly. Both CATTS treatments (chamber temperatures of $45^{\circ} \mathrm{C}$ or $47^{\circ} \mathrm{C}$ at $1 \mathrm{kPa} \mathrm{O}, 15 \mathrm{kPa}$ $\mathrm{CO}_{2}$, with humidity maintained at $2{ }^{\circ} \mathrm{C}$ below dew point) effectively controlled all stages of WCFF from naturally infested fruits (Neven and Rehfield-Ray, 2006a). We estimate that all egg and larval stages were represented in the infested fruit because we observed pupation from the control fruit for 3 weeks after treatment. We estimated that we treated and killed 6315 WCFFs in the $45{ }^{\circ} \mathrm{C}$ treatment and 5800 WCFFs in the $47{ }^{\circ} \mathrm{C}$ treatment (Table 1). Efficacy trials generally require killing 5000 of the most tolerant stage with zero survivorship. These studies indicate that CATTS can be effective in achieving control of WCFF in sweet cherries.

Sweet cherry quality. The two CATTS treatments developed to control both $\mathrm{CM}$ and WCFF were used to test commodity quality of sweet cherries (Neven and Drake, 1998, 2000a; Neven et al., 2001; Shellie et al., 2001). Neven and Drake (1998) found that heat-treated 'Bing' sweet cherries were slightly redder than untreated control fruit. Fruit and stem subjective visual values were slightly lower for the heat-treated fruit after $14 \mathrm{~d}$ of storage, but more pronounced for $21 \mathrm{~d}$ of storage. Firmness was unaffected. Soluble solid content (SSC) was unaffected, except for fruit stored under modified atmosphere packaging (MAP) for $14 \mathrm{~d}$, where values were higher in heat-treated fruit. Changes in titratable acidity (TA) were minimal. Pitting and bruising were more evident in heattreated fruit, but there was not any visible decay in CATTS treated cherries over all storage periods.

Neven and Drake (1998) found that there were no significant changes in fruit color of CATTS-treated 'Rainier' cherries. Stem color was slightly browner in CATTS-treated fruit stored for $21 \mathrm{~d}$ in MAP. Fruit and stem subjective visual values were slightly lower for CATTS-treated fruit. Firmness was slightly lower (but within $0.5 \mathrm{~N}$ ) for CATTStreated fruit. The effects of CATTS treatment on SSC and TA were not significant (SSC differences were usually higher for heattreated fruit). Both pitting and bruising were significantly higher in CATTS-treated fruit. No visible decay was found in any CATTS treatment.

Further research (Neven and Drake, 2000a) compared various potential quarantine treatments against conventional methyl bromide fumigation, and found that fruit quality of CATTS-treated cherries was superior to methyl bromide fumigated fruits, with the exception of pitting. Pitting was attributed to the low temperature of the hydrocooling water $\left(0-2{ }^{\circ} \mathrm{C}\right)$. Further studies using forced air cooling at $2{ }^{\circ} \mathrm{C}$ reduced this problem (Shellie et al., 2001). These treatments show great promise as both an alternative to methyl bromide fumigation for conventionally grown sweet cherries and a new treatment for organically grown sweet cherries.

\section{'BARTLETT' PEARS}

Codling moth and oriental fruit moth mortality. Two treatments were developed to control both CM and oriental fruit moth (OFM; Grapholitha molesta) in 'Bartlett' pears. The first treatment incorporated a heating rate of $12{ }^{\circ} \mathrm{C} / \mathrm{h}$ whereas the other used a heating rate of $100^{\circ} \mathrm{C} / \mathrm{h}$ from a starting chamber temperature of $23{ }^{\circ} \mathrm{C}$ to a final chamber temperature of $46{ }^{\circ} \mathrm{C}$ (Neven, 2004). We found that 'Bartlett' pears could tolerate a very rapid rate of heating while maintaining market quality (Mitcham et al., 1999). We found that we could obtain $100 \%$ 
mortality of CM and OFM in $2.5 \mathrm{~h}$ using the $100{ }^{\circ} \mathrm{C} / \mathrm{h}$ heating rate CATTS treatment, whereas it took $3 \mathrm{~h}$ to obtain the same level of mortality using the $12{ }^{\circ} \mathrm{C} / \mathrm{h}$ heating rate CATTS treatment (Neven, 2004).

Market quality. 'Bartlett' pears are one of the few fruits that cannot tolerate most traditional postharvest quarantine treatments designed to control insect pests like $\mathrm{CM}$ or OFM. Therefore, these fruit are not commonly exported to markets restricting these pests. Also, 'Bartlett' pears are not known to store for extended periods of time like apples and winter pears. Considerable time and effort is required when processing 'Bartlett' pears, which often requires canning operations to pay overtime to workers to ensure that the harvest is processed before commodity quality is lost as a result of overripening during storage. It is possible that heat treatments before cold storage could delay ripening, and therein give canners extra time to process the harvest. Previous research with apples and winter pears showed that CATTS treatments delayed ripening by 3 to $5 \mathrm{~d}$, which might also be the case for 'Bartlett' pears.

The quality of fruit directly after CATTS treatments was not significantly different from nonheated controls. We found that the longer the duration of the heat treatment, the firmer the pears after the ripening period. The levels of SSC were not significantly different between treatments, whereas there was a slight decrease in TA, less than $1 \%$, in the 3-h CATTS-treated cold-stored fruit after the 4-d ripening period. However, this decrease was not observed in the 7-d ripened fruit; for the CATTS-treated fruit, the TA values were slightly higher. There was an increase in external injury evident in the 2- and 3-h CATTS-treated cold-stored fruits, which may result from handling hot fruit after treatment. The $\mathrm{L}$ (Hunter L, measure of lightness) values of CATTS-treated coldstored fruits were slightly lower than controls, whereas the $\mathrm{H}$ (hue) values tended to be slightly increased at the 4-d but not the 7d ripening periods (Mitcham et al., 1999).

These data indicate that $\mathrm{CM}$ and OFM can be effectively controlled in 'Bartlett' pears with CATTS while maintaining commodity market quality.

\section{WINTER PEARS}

Winter pears, like summer pears, do not respond well to methyl bromide fumigations designed to control the two major internal feeding pests: CM and OFM. In addition, winter pears have not been widely exported because of issues with fire blight (Erwinia amylovora). However, in preliminary studies to determine the potential of CATTS for pest control in winter pears, we found that they respond quite well to heating rates of 4 to $12^{\circ} \mathrm{C} / \mathrm{h}$ to core temperatures between 43 and $45^{\circ} \mathrm{C}$ (Neven and Drake, 2000b; Neven et al., 2001). This is not surprising because these fruits, as well as apples, grown in Washington state commonly reach $42{ }^{\circ} \mathrm{C}$ at a rate of nearly $4{ }^{\circ} \mathrm{C} / \mathrm{h}$ during a typical summer day (Howell and Schmidt 2002). There was little difference in fruit quality when heat treatments were performed under air (Neven and Drake, 2000b) or under a $1 \mathrm{kPa} \mathrm{O}_{2}, 15$ $\mathrm{kPa} \mathrm{CO}_{2}$ environment (Neven et al., 2001). The addition of $\mathrm{CA}$ to the heat treatment did have a dramatic effect on CM mortality, which resulted in complete control of $\mathrm{CM}$ in less time compared with heat-only treatments (Neven and Rehfield-Ray, 2006b; Neven et al., 2001).

Winter pear quality. Controlled Atmosphere/Temperature Treatment System-treated 'Anjou' fruit were greener than controls, with hue values 12 to $15 \mathrm{U}$ higher than untreated controls (Neven and Drake 2000b, Neven et al., 2001). Firmness was higher in heat-treated fruit by more than $26 \mathrm{~N}$. Soluble solids concentration values were not appreciably changed by heat treatments compared with controls. Titratable acidity decreased slightly in treatments and was significantly lower than controls. The SSC-to-TA ratio was greatly increased in treatments, with values 16 to $25 \mathrm{U}$ higher than controls (Neven and Drake, 2000b; Neven et al., 2001).

Controlled Atmosphere/Temperature Treatment System-treated 'Bosc' fruit firmness was higher by as much as 26 to $40 \mathrm{~N}$ (Neven and Drake, 2000b; Neven et al., 2001). There were no appreciable changes in hue, SSC, and TA. The SSC-to-TA ratio was higher in treatments by nearly twofold (Neven and Drake, 2000b; Neven et al., 2001).

It is interesting to note that superficial scald was not noticed in any of the CATTStreated fruit, but was observed in some of the controls (Neven et al., 2001). These findings are in agreement with preliminary research performed in Israel (Klein, 1994; Klein and Lurie, 1992; Klein et al., 1990; Lurie et al., 1990, 1991). This is significant for the organic industry because there is no reliable means to prevent the development of superficial scald in pears that meet current organic standards.

\section{PEACHES AND NECTARINES}

Codling moth and OFM are the major pests of quarantine concern in peaches and nectarines grown in California and exported to Japan (CM), Mexico (OFM), and British Columbia, Canada (OFM). Although "systems" approaches have been approved by

Table 2. Summary of Controlled Atmosphere/Temperature Treatment System treatments for peaches and nectarines for control of codling moth (CM) and oriental fruit moth (OFM).

\begin{tabular}{|c|c|c|c|c|c|}
\hline $\begin{array}{l}\text { Heating rate } \\
\left({ }^{\circ} \mathrm{C} / \mathrm{h}\right)\end{array}$ & $\begin{array}{l}\text { Final chamber } \\
\text { temp }\left({ }^{\circ} \mathrm{C}\right)\end{array}$ & $\begin{array}{c}\text { Total treatment } \\
\text { time }^{\mathrm{y}}(\mathrm{min})\end{array}$ & $\begin{array}{c}\text { Final low core } \\
\text { temperature }\left({ }^{\mathrm{x}} \mathrm{C}\right)\end{array}$ & $\begin{array}{l}\text { CM killed }{ }^{\mathrm{w}} \\
\text { (n.) }\end{array}$ & $\begin{array}{c}\text { OFM killed } \\
\text { (n.) }\end{array}$ \\
\hline 12 & 46 & 180 & 44.0 & 31,154 & 5674 \\
\hline 24 & 46 & 150 & 45.2 & 30,884 & 5453 \\
\hline
\end{tabular}

${ }^{\mathrm{z}}$ Rate of temperature increase in the chamber.

yTotal treatment time from initial increase in temperature in the chamber until the fruit is removed from the chamber.

${ }^{\mathrm{x}}$ Final core low temperature of peaches and nectarines.

w Number of fourth instar codling moths (CM) killed with zero survivors in confirmation tests.

"Estimated number of fourth instar oriental fruit moths (OFM) killed with zero survivors in efficacy tests. All Controlled Atmosphere/Temperature Treatment System treatments conducted at $1 \mathrm{kPaO}_{2}, 15 \mathrm{kPaCO}_{2}$, with a dew point set at $2{ }^{\circ} \mathrm{C}$ below the lowest fruit surface temperature. 
2005, heat transfer was more problematic because of the location of the ventilation holes on the ends rather than along the sides of the boxes. We are currently working with the industry to construct a special commercial CATTS unit that could treat a pallet of boxed fruit, because this is their desired format for fruit treatment by the industry. We expect this chamber to be completed some time in 2007.

Peach and nectarine quality. Fruit quality was very similar for both heating rates. Compared with the untreated controls, CATTS-treated fruit displayed slightly higher amounts of surface injury, although the increase in surface injury was only an important factor to marketability in cultivars that had high amounts of surface injury before treatment (Obenland et al., 2005). The percentage of free juice in the flesh, a measure of juiciness, was slightly less in CATTS-treated fruit early in storage but was often greater in treated fruit toward the end of the storage period. Slower rates of softening during fruit ripening were apparent in CATTS-treated fruit. Soluble solids, acidity, weight loss, and color all were either unaffected or changed to a very small degree as a result of CATTS treatment. Members of a trained sensory panel preferred the taste of untreated fruit over fruit that had been CATTS-treated, but the ratings of treated and nontreated fruit were generally close together and it is unclear whether an average consumer could detect the difference (Obenland et al., 2005). The fact that we did not find significant differences in treatment efficacy between peaches and nectarines indicates that this treatment is equally effective for both types of fruit (Obenland et al., 2005). The reason for this may be related to the slow rate of heating used in this system. Although further work needs to be done regarding the influence of CATTS on taste, it otherwise appears that CATTS treatment does not adversely affect the marketability of goodquality fruit and therefore shows promise as a nonchemical quarantine treatment for peaches and nectarines. These treatments are an improvement over traditional methyl bromide fumigation in that they extend shelf life (Obenland et al., 2005).

These CATTS treatments were demonstrated to provide complete control of the two major quarantine pests infesting peaches and nectarines. These treatments are efficacious

Table 3. Summary of Controlled Atmosphere/Temperature Treatment System treatments for apples for control of codling moth $(\mathrm{CM})$ and oriental fruit moth (OFM).

\begin{tabular}{lccccc}
\hline $\begin{array}{l}\text { Heating rate } \\
\left({ }^{\circ} \mathrm{C} / \mathrm{h}\right)\end{array}$ & $\begin{array}{c}\text { Final chamber } \\
\text { temp }\left({ }^{\circ} \mathrm{C}\right)\end{array}$ & $\begin{array}{c}\text { Total treatment } \\
\text { time }^{\mathrm{y}}(\mathrm{min})\end{array}$ & $\begin{array}{c}\text { Final core } \\
\text { low temperature } \\
\left({ }^{\circ} \mathrm{C}\right)\end{array}$ & $\begin{array}{c}\text { CM killed } \\
(\mathrm{n} .)\end{array}$ & $\begin{array}{c}\text { OFM killed }^{\mathrm{v}} \\
(\mathrm{n} .)\end{array}$ \\
\hline 12 & 46 & 180 & 43.5 & 30861 & 5497 \\
\hline
\end{tabular}

${ }^{2}$ Rate of temperature increase in the chamber.

${ }^{\mathrm{y}}$ Total treatment time from initial increase in temperature in the chamber until the fruit is removed from the chamber.

${ }^{\mathrm{x}}$ Final core low temperature of peaches and nectarines.

wNumber of fourth instar codling moths (CM) killed with zero survivors in confirmation tests.

vEstimated number of fourth instar oriental fruit moths (OFM) killed with zero survivors in efficacy tests. All Controlled Atmosphere/Temperature Treatment System treatments conducted at $1 \mathrm{kPaO}_{2}, 15 \mathrm{kPa} \mathrm{CO}_{2}$, with a dew point set at $2{ }^{\circ} \mathrm{C}$ below the lowest fruit surface temperature. chamber temperatures of 44 or $46{ }^{\circ} \mathrm{C}$, with humidity maintained at $2{ }^{\circ} \mathrm{C}$ below dew point, $2 \mathrm{~ms}^{-1}$ air speed, at $1 \mathrm{kPaO} \mathrm{O}_{2}$ and 15 $\mathrm{kPa} \mathrm{CO}_{2}$ ) (Neven et al., 2001). All heattreated fruit were firmer than untreated control fruit. Heat-treated fruit stored as long as the untreated control fruit. In 'Golden Delicious' apples, sunburn was more prevalent in control fruit but not as common in heattreated fruit. 'Gala' apples were more susceptible to internal breakdown after heat plus CA treatments. 'Red Delicious' apples withstood the treatments very well. 'Fuji' apples at harvest had severe water core and did not withstand more than $90 \mathrm{~d}$ of storage. 'Granny Smith' apples stored for $150 \mathrm{~d}$ showed a dramatic suppression of storage scald in the heat-treated fruit. Control fruit had 100\% scald whereas heat-treated fruit were showed less than $1 \%$ storage scald. In all heat-treated fruit, the SSC-to-TA ratio was increased, which is generally reflected in a sweeter tasting fruit.

\section{SUMMARY}

The CATTS treatment effectively controlled all stages of CM, OFM, and WCFF that infest fresh fruit. We have demonstrated that CATTS treatments can be effective in both laboratory and commercial CATTS units for apples. We have also demonstrated from previous research that CATTS treatment can result in acceptable apple (Neven et al., 2001), peach and nectarine (Obenland et al., 2005), sweet cherry (Neven and Drake, 2000a; Neven et al., 2001; Shellie et al., 2001), and pear (Mitcham et al., 1999; Neven et al., 2001) quality. We believe that this treatment can provide quarantine security for export of organic tree fruits attempting to gain market access to countries currently requiring direct postharvest quarantine treatments while maintaining organic certification.

\section{Literature Cited}

Armstrong, J.W. 1994. Heat and cold treatments, $p$. 103-119. In: R.E. Paull and J.W. Armstrong (eds.). Insect pests and fresh horticultural products: Treatments and responses. CAB International, Wallingford, UK.

Hallman, G.J. 1994. Controlled atmospheres, p. 121-136. In: R.E. Paull and J.W. Armstrong (eds.). Insect pests and fresh horticultural products: Treatments and responses. CAB International, Wallingford, UK.

Hansen, J.D. and L.J. Rehmke. 2003. Field survival of codling moth (Lepidoptera: Tortricidae) on artificially infested sweet cherries. Crop Protection J. 22:721-727.

Howell, J.F. and R.S. Schmidt. 2002. Codling moth (Lepidoptera: Tortricidae): Development at constant and at orchard temperatures. J. Agr. Urban Entomol. 19:15-23.

Klein, J.D. 1994. Time, temperature, and calcium interact in scald reduction and firmness retention in heated apples. HortScience 29:194-195.

Klein, J.D. and S. Lurie. 1992. Prestorage heating of apple fruit for enhanced postharvest quality: Interaction of time and temperature. HortScience 27:326-328.

Klein, J.D., S. Lurie, and R. Ben-Arie. 1990. Postharvest heat treatment as a possible means 
of reducing superficial scald of apples. HortScience 65:503-509.

Lurie, S., J.D. Klein, and R. Ben-Arie. 1990. Quality and cell wall components of 'Anna' and 'Granny Smith' apples treated with heat, calcium, and ethylene. J. Amer. Soc. Hort. Sci. 115:954-958.

Lurie, S., J.D. Klein, and R. Ben-Arie. 1991. Prestorage heat treatment delays development of superficial scald on 'Granny Smith' apples. HortScience 26:166-167.

McEvoy, M. 2003. Organic certification in the United States and Europe. 9 Oct. 2007. <http:// postharvest.tfrc.wsc.edu/PC2003.pdf>.

Mitcham, E.J., L. Neven, and B. Biasi. 1999. Effect of high-temperature controlled-atmosphere treatments for insect control in 'Bartlett' pear fruit. HortScience 34:527.

Moffitt, H.R., S.R. Drake, H.H. Toba, and P.L. Hartsell. 1992. Comparative efficacy of methyl bromide against codling moth (Lepidoptera: Tortricidae) larvae in 'Bing' and 'Rainier' cherries and confirmation of efficacy of a quarantine treatment for 'Rainier' cherries. J. Econ. Entomol. 85:1855-1858.

National Organic Program. 2006. <http://www. ams.usda.gov/nop/indexIE.htm $>$.

Neven, L.G. 1998a. Effects of heating rate on the mortality of fifth instar codling moth. J. Econ. Entomol. 91:297-301.

Neven, L.G. 1998b. Respiratory response of fifth instar codling moth to rapidly changing temperatures. J. Econ. Entomol. 91:302-308.

Neven, L.G. 2000. Insect physiological responses to heat. Postharv. Biol. Technol. 21: $103-111$.

Neven, L. 2003. Effects of physical treatments on insects. HortTechnology 13:272-275.

Neven, L.G. 2004. Hot forced air with controlled atmospheres for disinfestation of fresh commodities, p. 297-315. In: R. Dris and S.M. Janin (eds.). Production practices and quality assessment of food crops., Vol. 4. Post harvest treatments. Kluwer Academic Publishers, Dordrecht, The Netherlands.

Neven, L.G. 2005. Combined heat and controlled atmosphere quarantine treatments for control of codling moth, Cydia pomonella, in sweet cherries. J. Econ. Entomol. 98:709-715.

Neven, L.G. and S.R. Drake. 1998. Quarantine treatments for sweet cherries. Good Fruit Grower. 49:43-44.

Neven, L.G. and S.R. Drake. 2000a. Comparison of alternative quarantine treatments for sweet cherries. Postharv. Biol. Technol. 20:107-114.
Neven, L.G. and S.R. Drake. 2000b. Effects of the rate of heating on apple and pear fruit quality. J. Food Qual. 23:317-325.

Neven, L.G., S.R. Drake, and K. Shellie. 2001. Development of a high temperature controlled atmosphere quarantine treatment for pome and stone fruits. Acta Hort. 553:457-460.

Neven, L. and E. Mitcham. 1996. CATTS (Controlled Atmosphere/Temperature Treatment System): A novel tool for the development of quarantine treatments. Amer Entomol. 42:56-59.

Neven, L. and L. Rehfield. 1995. Comparison of pre-storage heat treatments on fifth instar codling moth (Lepidoptera: Tortricidae) mortality. J. Econ. Entomol. 88:1371-1375.

Neven, L.G., L.M. Rehfield, and K.C. Shellie. 1996. Moist and vapor forced air treatments of apples and pears: Effects on the mortality of fifth instar codling moth (Lepidoptera: Tortricidae). J. Econ. Entomol. 89:700-704.

Neven, L.G. and L.M. Rehfield-Ray. 2006a. Combined heat and controlled atmosphere quarantine treatment for control of Western cherry fruit fly in sweet cherries. J. Econ. Entomol. 99:658-663.

Neven, L.G. and L. Rehfield-Ray. 2006b. Confirmation and efficacy tests against codling moth, Cydia pomonella and oriental fruit moth, Grapholitha molesta, in apples using combination heat and controlled atmosphere treatments. J. Econ. Entomol. 99:1620-1627.

Neven, L.G., L. Rehfield-Ray, and D. Obenland. 2006. Confirmation and efficacy tests against codling moth and oriental fruit moth in peaches and nectarines using combination heat and controlled atmosphere treatments. J. Econ. Entomol. 99:1610-1619.

Northwest Horticultural Council. 2006. Export manual. 9 Oct. 2007. <http://www.nwhort.org/>.

Obenland, D., P. Neipp, B. Mackey, and L.G. Neven. 2005. Peach and nectarine quality following treatment with high temperature forced air combined with controlled atmospheres. HortScience 40:1425-1430.

Shellie, K.C., L.G. Neven, and S.R. Drake. 2001. Assessing 'Bing' sweet cherry tolerance to a heated controlled atmosphere for insect pest control. HortTechnology 11:308-311.

Wang, S., S.L. Birla, J. Tang, and J.D. Hansen. 2006. Postharvest treatment to control codling moth in fresh apples using water assisted radio frequency heating. Postharv. Biol. Technol. 40:89-96.

Wearing, C.H., J.D. Hansen, C. Whyte, C.E. Miller, and J. Brown. 2001. The potential for spread of codling moth (Lepidoptera: Tortricidae) via commercial sweet cherry fruit: A critical review and risk assessment. Crop Protect. J. 20:465-488.

Whiting, D.C. and L.E. Hoy. 1997. High-temperature controlled atmosphere and air treatments to control obscure mealybug (Hemiptera: Pseudococcidae) on apples. J. Econ. Entomol. 90:546-550.

Whiting, D.C., L.E. Jamieson, K.J. Spooner, and M. Lay-Yee. 1999. Combination high-temperature controlled atmosphere and cold storage as a quarantine treatment against Ctenopseustis obliquana and Epiphyase postvittana on 'Royal Gala' apples. Postharv. Biol. Technol. 16: 119-126.

Whiting, D.C., G.M. O'Connor, J. Van Den Heuvel, and J.H. Maindonald. 1995. Comparative mortalities of six Tortricid (Lepidoptera) species to two high-temperature controlled atmospheres and air. J. Econ. Entomol. 88:13651370.

Yahia, E.M. 2000a. Mortality of eggs and third instar larvae of Anastrepha ludens and $A$. obliqua with insecticidal controlled atmospheres at high temperatures. Postharv. Biol. Technol. 20:295-302.

Yahia, E.M. 2000b. Responses and quality of mango fruit treated with insecticidal controlled atmospheres at high temperatures. Acta Hort. 509:479-486.

Yahia, E.M. 2000c. The mortality of artificially infested third instar larvae of Anastrepha ludens and A. obliquia in mango fruit with insecticidal controlled atmospheres at high temperatures. Acta Hort. 509:833-839.

Yin, X., S. Wang, J. Tang, S. Lurie, and J.D. Hansen. 2006. The effect of thermal preconditioning on heat shock protein in fifth instar codling moth (Lepidoptera: Toretricidae). Physiol. Entomol. 31:241-247.

Yocum, G. and D.L. Denlinger. 1994. Anoxia blocks thermotolerance and the induction of rapid cold hardening in the flesh fly, Sarcophaga crassipalpis. Physiol. Entomol. 19:152-158.

Yokoyama, V.Y. and G.T. Miller. 1987. High temperature for control of oriental fruit moth (Lepidoptera: Tortricidae) in stone fruit. J. Econ. Entomol. 80:641-645.

Yokoyama, V.Y., G.T. Miller, and R.V. Dowell. 1991. Response of codling moth (Lepidoptera: Tortricidae) to high temperature: A potential quarantine treatment for exported commodities. J. Econ. Entomol. 84: 528-531. 